\title{
It, læringsressourcer og nye undervisningsmiljøer
}

DUT overgår fra og med dette nummer til alene at være et elektronisk tidsskrift og vil fremover være at finde på Statsbibliotekets Open Journal Systems. Vi håber med dette tiltag, at Dansk Universitetspædagogisk Tidsskrift vil blive læst af endnu flere og således nå en større udbredelse.

Temadelen i dette nummer af Dansk Universitetspædagogisk Tidsskrift har overskriften it, læringsressourcer og nye undervisningsmiljøer.

Universiteterne har de seneste år i stadig højere grad interesseret sig for it-understøttede platforme til den daglige drift - også den specifikt undervisningsrelaterede. Universitetsundervisere har ligeledes med stadig større volumen fokuseret på pædagogiske og didaktiske tiltag, hvor it, her begrebsliggjort med betegnelserne digitale medier og netmedierede kommunikationsfora, har været brugt såvel som et supplement til mere traditionelle læringsressourcer og som et omdrejningspunkt for undervisningskommunikation. Begrebet it inkluderer således f.eks. podcasts, video, clickers, sociale netværk, delingstjenester, samarbejdsværktøjer, referencetjenester, blogs og feeds.

Historien fortæller, at it i sig selv ikke udgør nytænkning. Således er det f.eks. ikke i sig selv nødvendigvis nytænkning at implementere et LMS-system (Learning-Management-System). Systemet i sig selv kan være ganske traditionelt i sin attitude og logik, hvad angår brugernes behov, aktivitetsmuligheder og grundlæggende antagelser om, hvad universitetsundervisning skal præstere. Samtidig kan både et traditionelt LMSsystem men også nyere teknologiske løsninger på undervisere og studerendes behov ses som et potentiale, når det drejer sig om nytænkning af undervisning og studerendes studierelaterede aktiviteter.

De videnskabelige artikler har fokus på teknologiske muligheder i form af læringsunderstøttende ressourcer og nye undervisningsmiljøer men også på barrierer bl.a. $i$ form af underviseres og studerendes forventninger til begrebet undervisning og til hvilke aktiviteter dette indebærer. Hertil kommer universiteternes forskellige it-løsninger, hvor nogle har valgt en fælles platform som fundament, andre en hybrid, hvor gratis tjenester og værktøjer hentes fra 'skyen'. Endelig er der eksempler på teknologiske løsninger der har 'skyen' som omdrejningspunkt.

Artiklerne peger, udover muligheder og barrierer, også på, at brug af it fremkalder typer af faldgruber, som undervisere og studerende må reflektere og handle på.

Med de fire videnskabelige artikler, der på hver deres måde kobler universitetsundervisning med brugen af digitale medier og netmedierede fora, byder dette nummer af Dansk Universitetspædagogisk Tidsskrift til fortsat udvikling og samarbejde om universitetspædagogiske og -didaktiske udfordringer.

Udover temarelaterede artikler præsenteres der i dette nummer to artikler, hvor den ene omhandler fagdidaktik i relation til ingeniørstuderende, mens den anden artikel relaterer til temaet $i$ og med, at den formidler en læringsressource i form af et enkelt didaktisk redskab, der kan tages $i$ anvendelse af alle universitetsundervisere. Endelig er der til sidst i tidsskriftet anmeldelse af to universitetspædagogiske bøger.

Nedenfor følger referater af de enkelte artikler.

Christian Dalsgaards artikel Personlige læringsmiljøer: Universitetsuddannelse på internettet tager afsæt $i$, at e-læringssystemer $i$ universitetssammenhæng ofte kun anvendes ud fra en institutionel vinkel og derfor primært understøtter underviserens og ikke den studerendes aktiviteter. Der argumenteres for, at hvis e-læring bringes ud over den institutionelle ramme ved brug af internettet som en læringsressource målrettet den studerendes egne formål, så vil dette i højere grad understøtte den enkelte studerendes læring $\mathrm{i}$ form af et personligt læringsmiljø.

I artiklen Erfaringer med e-porteføljer og personlige læringsmiljøer præsenterer Thomas Ryberg og Helle Wentzer erfaringer med e-porteføljer og personlige læringsmiljøer brugt på 1. semester BA i 
Humanistisk Informatik, AAU. Disse it-redskaber blev indført for at imødekomme behovet for mere personlige og kollektive læringsrum for store studenterårgange. Erfaringerne er blandede: De overordnede intentioner om at skabe faglig dialog og mulighed for løbende refleksion i porteføljen møder forståelse og positiv respons hos i hvert fald en del af de studerende, men systemerne opleves som svære at bruge og/eller som overflødige, når de studerende samtidig anvender andre it-systemer.

Karin Tweddell Levinsens artikel Udfordringer i netværksamfundet - digitale kompetencer og it i nye undervisningsmiljøer fokuserer på opnåelse af selvprogrammering og it-dannelse hos voksne mennesker, der ikke er født ind i digitaliseringen. Artiklen tager udgangspunkt $i$ en konkret case fra en teknologirelateret workshop på kandidatuddannelsen i it-didaktisk design, hvor deltagerne arbejdede med selviagttagelse og refleksion over egne læringsstrategier. På baggrund af dette blev der gennemført en fænomenologisk analyse af udvalgte deltageres læreproces. Det konkluderes i artiklen, at fire dimensioner er væsentlige i it-relaterede læreprocesser: Strategi, kompleksitetshåndtering, refleksivitet og kropsforankring.

Artiklen Clickers, en læringsunderstøttende ressource? af Helle Mathiasen sætter fokus på brugen af clickers i universitetsundervisning. Efter en kort state of the art præsentation indsættes brugen af clickers $i$ et systemteoretisk perspektiv, idet dets funktion som kommunikativt redskab diskuteres. I artiklen inddrages empiriske undersøgelser i form af observation og interview med studerende. På denne baggrund gennemføres en diskussion af brugen af clickers som en læringsunderstøttende ressource.

Claus Thorp Hansens artikel Udvikling af et kursus i konceptsyntese for forskellige ingeniørstuderende er et fagdidaktisk forslag til, hvordan man som underviser på ingeniørstudier kan gennemføre en revision af et kursus ved anvendelse af Jank og Meyers didaktiske model. Kursets genstand er konceptualisering, hvor konceptualisering handler om at designe og således at skabe nyt på baggrund af et brugerbehov. Udfordringen for revisionen af kurset var, at ingeniørstuderende fra forskellige studieretninger fremover skulle deltage i kurset, hvorfor målgruppen var studerende med forskellige faglige forudsætninger. Forskellige løsningsforslags styrker og svagheder blev overvejet med baggrund i fagdidaktiske analyser, og en helhedsløsning for et generisk kursus blev skabt. Resultatet var beskedne ændringer i kursets indhold, dannelse af kursets projektgrupper og sekvensen i kursets projektaktiviteter. Kurset afvikledes forste gang i den reviderede udgave i 2009, hvor der deltog 26 studerende fra 4 kandidatretninger.Vurderet ud fra de studerendes kursusevalueringer og de opnåede karakterer må kursets revision anses som værende en succes.

Mads Hovgaards værktøjsartikel Stemmekort - et didaktisk værktøj til deltagerinvolvering, feedback og faglig dialog tilbyder et billigt og praktisk alternativ til clickers med de samme gevinster i form af deltagerinvolvering, hurtig individuel feedback og generelt engagerede studerende. Forfatteren har selv udviklet og afprøvet Stemmekort og deler i artiklen ud af sine erfaringer med både anvendelsen og effekten, og argumenterer for, at tabet ved at erstatte clickers med stemmekort er begrænset og til dels kan vendes til fordele.

Vi modtager løbende artikelforslag. Send disse direkte via http://ojs.statsbiblioteket.dk/index.php/dut/index. du kan også kontakte redaktionen direkte på dut@ dun-net.dk. 